ks. Jerzy Adamczyk

Wyższe Seminarium Duchowne w Radomiu

\title{
Wybrane formy przepowiadania słowa Bożego w parafii (kan. 770 KPK)
}

Instrukcja Kapłan, pasterz i przewodnik wspólnoty parafialnej, mówiąc o posłudze głoszenia słowa Bożego w parafii, przypomina: „kan. 528, który podkreśla odpowiedzialność proboszcza za głoszenie Bożego słowa i za przekazywanie autentycznej nauki katolickiej, wymienia wyraźnie homilię i nauczanie katechetyczne. [...] Św. Jan xxiıI pisał, że «jest ogromnie ważne, aby duchowni wszędzie i w każdym czasie byli wierni swemu obowiązkowi nauczania». Natomiast św. Pius x mówił w związku z tym: «Trzeba tylko to podkreślać i na to kłaść nacisk, że jest to najpoważniejszy obowiązek każdego kapłana, że jest to najdonioślejsze zadanie, które na nim spoczywa»"'.

Prawodawca kościelny w kodeksie prawa kanonicznego [dalej: KPK] z naciskiem podkreśla podstawowy obowiązek proboszcza troszczenia się o to, ażeby przybywającym w parafii głoszone było nieskażone słowo Boże. Ma on zabiegać o to, by wierni byli właściwie o prawdach wiary pouczani².

Nowa ewangelizacja, czyli głoszenie zawsze tej samej Ewangelii Chrystusowej, ale $\mathrm{w}$ nowych warunkach, $\mathrm{z}$ nową mocą, za pomocą argumentacji przemawiających do współczesnej mentalności człowieka, poprzez nowe środki, winna się dokonywać różnorodnymi sposobami, spośród których

\footnotetext{
1 Congregazione per il Clero, Istruzione Il presbitero, pastore e guida della comunità parrocchiale, 4.08.2002, Città del Vaticano 1999, nr 20; tekst polski: Kongregacja ds. Duchowieństwa, Instrukcja Kapłan, pasterz i przewodnik wspólnoty parafialnej, Poznań 2002.

2 Zob. kan. $528 \$ 1$.
} 
fundamentalne znaczenie ma funkcja przepowiadania słowa Bożego, w tym głoszenie kazań3.

Prawodawca kodeksowy, zobowiązując do wygłaszania homilii eucharystycznej we wszystkich mszach świętych w niedziele i święta nakazane odprawianych $\mathrm{z}$ udziałem wiernych ${ }^{4}$, zaznacza jednocześnie, że wspomniana homilia zajmuje szczególne miejsce wśród różnych form przepowiadania. W kan. 770 kodeks mówi o „innych formach przepowiadania” (różnych od misji czy rekolekcji parafialnych) dostosowanych do miejscowych potrzeb, które proboszczowie winni organizować zgodnie z zarządzeniem biskupa diecezjalnego ${ }^{5}$, a kan. $528 \$ 1$ o głoszeniu zwłaszcza homilii w niedziele i święta nakazane. Skoro przytoczone teksty prawne wskazują, że oprócz homilii czy misji oraz rekolekcji parafialnych istnieją inne (różne) formy przepowiadania słowa Bożego, to powstaje pytanie: jakie są to formy, jaka jest ich natura, na jakich źródłach winny się opierać, jakie znaczenie ma prawo partykularne odnośnie do stosowania tych „innych form przepowiadania”, skoro można lub trzeba je realizować zgodnie z zarządzeniem biskupa diecezjalnego?

Niniejszy artykuł będący odpowiedzią na postawione problemy naukowe podejmujące następujące zagadnienia: 1. Różne formy przepowiadania w parafii; 2. Źródła i treść „innych form przepowiadania” słowa Bożego; 3. Ważniejsze rodzaje przepowiadania parafialnego.

\section{Różne formy przepowiadania w parafii}

Według kan. $515 \$ 1$ pasterską pieczę nad parafią, będącą określoną wspólnotą wiernych, utworzoną na sposób stały w Kościele partykularnym, pod władzą biskupa diecezjalnego, sprawuje proboszcz, jako jej własny pasterz. Także kan. 519 nazywa proboszcza własnym pasterzem zleconej sobie parafii. Pasterz własny (pastor proprius) parafii to ten, którego misja duszpasterska nie jest doraźna i przypadkowa ani delegowana; do jej pełnienia został on powołany na podstawie uczestniczenia wraz z biskupem w kapłaństwie Chrystusa i powierzonego sobie urzędu ${ }^{6}$. Swoje uprawnienia i obowiązki

3 Por. J. Dyduch, Misja przepowiadania w powszechnym prawodawstwie kościelnym, w: Stuga Słowa, red. W. Przyczyna, Kraków 1997, s. 23-24.

4 Zob. kan. $767 \$ 2$.

5 Zob. kan. $772 \$ 1$.

6 Por. T. Pawluk, Prawo kanoniczne według Kodeksu Jana Pawła II, t. 2: Lud Boży, jego nauczanie i uświęcanie, Olsztyn 1986, s. 262-263. 
otrzymuje on za pośrednictwem urzędu powierzonego mu przez biskupa. Jego władza jest zwyczajna i w swoim zakresie własna, czyli wykonuje on ją $\mathrm{w}$ imieniu własnym ${ }^{7}$.

Proboszcz uczestniczy w posłudze Chrystusa, ażeby dla wspólnoty parafialnej wykonywał zadania nauczania, uświęcania i kierowania, przy współpracy także innych prezbiterów i diakonów oraz niosących pomoc wiernych świeckich, zgodnie z przepisami prawa ${ }^{8}$. Tak więc jako pasterzowi własnemu przysługują mu zadania nauczania, uświęcania i zarządzania. Jest on ustanowiony dla parafii, wspólnota parafialna ma więc prawo domagania się od niego pełnienia wymienionych zakresów posług. Jedną z zasadniczych posług w parafii jest przepowiadanie słowa Bożego.

Kanon 528, podkreślając odpowiedzialność proboszcza za głoszenie słowa Bożego i za przekazywanie autentycznej nauki katolickiej, wymienia wyraźnie homilię. Wśród środków przekazu słowa Bożego w parafii szczególne miejsce zajmuje homilia, będąca częścią liturgii ${ }^{9}$. Homilia (gr. homilein - być razem, rozmawiać) to „rodzaj przepowiadania kościelnego, polegający na popularnym wyjaśnianiu, komentowaniu, aktualizacji i praktycznym zastosowaniu tekstów biblijnych”10. Takie przepowiadanie jest „poufną rozmową kaznodziei

7 Por. J. Krukowski, Komentarz do kan. 519, w: Komentarz do Kodeksu Prawa Kanonicznego, t. 2: Ks. II/1: Lud Boży, red. J. Krukowski, Poznań 2005, s. 417-418.

8 Zob. kan. 519.

9 „Wśród różnych form przepowiadania szczególne miejsce zajmuje homilia. Stanowi ona część samej liturgii” (kan. $767 \$$ 1); por. kan. $386 \$ 1$; kan. $528 \$$ 1; E. Miragoli, Il termine „omelia” nei documenti della Chiesa, nei libri liturgici e nel Codice, „Quaderni di diritto ecclesiale” 11 (1998) n. 4 , s. 355 .

${ }^{10}$ M. Brzozowski, Homilia, w: Encyklopedia katolicka, red. J. Walkusz, t. 6, Lublin 1993, k. 1175. „Chociaż bowiem słowo Boże zawarte w czytaniach Pisma świętego zwraca się do wszystkich ludzi każdego czasu i jest dla nich zrozumiałe, jego pełniejsze rozumienie i skuteczność pogłębiają się dzięki żywemu wykładowi, czyli homilii, która jest częścią czynności liturgicznej” (Missale Romanum ex decreto sacrocancti Oecumenici Concilii Vaticani II instauratum, auctoritate Pauli Pp. vi promulgatum, Ioannis Paulis Pp. II cura recognitum, editio typica tertia, 20.04.200o, Typis Polyglottis Vaticanis 2002, nr 29; tekst polski: Kongregacja ds. Kultu Bożego i Dyscypliny Sakramentów, Ogólne wprowadzenie do Mszału rzymskiego, 20.04.200o, Poznań 2004, nr 29; por. nr 55). „Homilia więc, będąc wyjaśnieniem słowa Pisma Świętego, które zostało odczytane, czy też jakiegoś tekstu liturgicznego, winna prowadzić wspólnotę wiernych do czynnego sprawowania Eucharystii" (Ordo Lectionum Missae, Editio typica altera, Libreria Editrice Vaticana 1981, Praenotanda, $\mathrm{nr}$ 24, tłum. własne); por. J. Fuentes, Comentario al can. 767, w: Comentario exegético al Código de Derecho Canónico, coord. y dirigida A. Marzoa, J. Miras, R. Rodríguez-Ocaña,vol. 3/1, Pamplona $2002^{3}$, s. 115 . 
z wiernymi w ramach czynności liturgicznych o tekście biblijnym lub liturgicznym, który zaproponowała liturgia danego dnia" ${ }^{\prime 1}$.

Homilia eucharystyczna, jako część samej liturgii, jest zarezerwowana dla kapłana lub diakona. W ciągu roku liturgicznego należy wykładać w niej na podstawie świętych tekstów tajemnice wiary oraz zasady życia chrześcijańskiego. Homilia jest obowiązkowa i nie wolno jej opuszczać bez poważnej przyczyny. Winna być głoszona podczas wszystkich mszy świętych w niedziele i święta nakazane, odprawianych $\mathrm{z}$ udziałem wiernych. Natomiast gdy jest odpowiednia liczba wiernych, bardzo zaleca się homilię także w mszach świętych odprawianych w ciągu tygodnia, zwłaszcza w okresie adwentu i wielkiego postu, albo z racji jakiegoś święta lub wydarzenia żałobnego. Proboszcz ma czuwać, by te przepisy były wiernie przestrzegane $e^{12}$.

Kanon 528 zobowiązuje proboszcza, by troszczył się o to, ażeby przebywającym w parafii głoszone było nieskażone słowo Boże. Stąd zabiega o to, by wierni byli właściwie o prawdach wiary pouczeni, zwłaszcza przez głoszenie homilii w niedziele i święta nakazane. Sformułowanie „zwłaszcza przez głoszenie homilii” wskazuje na inne, prócz homilii, formy przepowiadania słowa Bożego, w tym niewątpliwie na misje ludowe i rekolekcje, jako nadzwyczajne akcje w ramach posługi słowa Bożego. Kanon 770 mówi o organizowaniu misji ludowych i rekolekcji, co wskazuje na obowiązek angażowania się proboszcza i współpracowników parafialnych w realizację tych form przepowiadania.

Można powiedzieć, że w aspekcie kanonicznym misje parafialne jest to organizowana przez proboszczów w pewnych okresach, zgodnie z zarządzeniem biskupa diecezjalnego, nadzwyczajna (przejściowa) działalność ewangelizacyjna, trwająca przez określony czas, polegająca na głoszeniu słowa Bożego, sprawowaniu sakramentów i celebracjach misyjnych (pobożnych ćwiczeniach), prowadzona przez uprawniony zespół misyjny przybywający spoza parafii, których celem jest gruntowna odnowa i ożywienie życia chrześcijańskiego wiernych ${ }^{13}$.

${ }^{11}$ W. Głowa, Liturgia miejscem i źródłem przepowiadania, Przemyśl 1999, s. 102.

${ }_{12}$ Por. kan. 767; por. kan. $528 \$ 1$. Trzeba zauważyć, że oprócz obowiązku głoszenia homilii $\mathrm{w}$ dniach świątecznych nie ma normy prawa powszechnego zobowiązującej do innych od homilii form przepowiadania. Kanon 770 mówi o stosowności innych form przepowiadania, różnych od homilii mszalnej, które w zależności od tego, co ustala prawo partykularne, mogłoby stać się obowiązkowe lub zalecane dla proboszczów. Por. J. Fuentes, Comentario al can. 770, w: Comentario exegético al Código de Derecho Canónico, dz. cyt., s. 124.

${ }_{13}$ Por. KPK, kan. 770; Pontificia Commissio Codici Iuris Canonici Recognoscendo, Schema canonum libri III - De ecclesiae munere docendi, Città del Vaticano 1977; tekst polski: Posoborowe 
Z kolei rekolekcje parafialne jest to organizowana przez proboszczów w pewnych okresach, zgodnie z zarządzeniem biskupa diecezjalnego, nadzwyczajna (przejściowa) działalność ewangelizacyjna, trwająca przez określony czas, na którą składa się zespół praktyk, takich jak medytacje, słuchanie słowa Bożego, modlitwa, rachunek sumienia, przeznaczone dla ogółu dorosłych parafian lub dla poszczególnych stanów, czy też dla specjalnych kategorii uczestników rekrutujących się z miejscowych parafian albo z gości przybywających $\mathrm{z}$ innych parafii, prowadzona przez uprawnionych szafarzy przybywających spoza parafii, których celem jest pogłębienie życia chrześcijańskiego wiernych ${ }^{14}$.

Jednak przepowiadanie w parafii nie ogranicza się tylko do wyliczonych wyżej form głoszenia słowa Bożego. Kanon 528, zobowiązując proboszcza do troski „Zwłaszcza o głoszenie homilii w niedziele i święta nakazane”, przewiduje oprócz rekolekcji i misji także ,inne formy przepowiadania dostosowane do miejscowych potrzeb" (alias formas necessitatibus aptatas) ${ }^{15}$. Należy zauważyć, że wspomniane „inne formy przepowiadania” nie występowały w schemacie kodeksu z 1977 roku, gdzie zapisano „proboszczowie, w tym także członkowie instytutów życia konsekrowanego, powinni organizować w pewnych okresach - zgodnie z przepisami Konferencji Biskupiej - rekolekcje czy misje, podczas których przedstawia się wiernym podstawowe prawdy nauki chrześcijańskiej”' ${ }^{’ 16}$.

prawodawstwo kościelne, zebr. i przetł. E. Sztafrowski, t. 11, z. 1, Warszawa 1980, nr 21077-21259, can. 23; G. Siwek, Misje ludowe w teorii i praktyce Kościoła. Studium homiletyczne, Kraków 1999, s. 150-151; G. Siwek, Misje ludowe, w: Leksykon teologii pastoralnej, red. R. Kamiński, W. Przygoda, M. Fiałkowski, Lublin 2006, s. 501; J. Fuentes, Comentario al can. 77o, dz. cyt., s. 124-125; F. Bączkowicz, J. Baron, W. Stawinoga, Prawo kanoniczne. Podręcznik dla duchowieństwa, t. 2, Opole 1958, s. 482.

${ }^{14}$ Por. F. Morrisey, The Teaching Office of the Church can. 770, w: The Canon Law Letter and Spirit a Practical Guide to the Code of Canon Law. Prepared by the Canon Law Society of Great Britain and Ireland in Association with The Canadian Canon Law Society, ed. F. Morrisey, London 1999, s. 426. „Rekolekcje są uprzywilejowanym narzędziem słuchania słowa Bożego, ich celem jest rewizja życia i odnowienie zobowiązania do chrześcijańskiego świadectwa" (Diocesi di Milano. $47^{\circ}$ sinodo, Milano 1995, parte I, cap. I, st. $46 \$ 2$ b, s. 8 [tłum. własne]).

15 M. Rivella zaznacza, że (oprócz misji i rekolekcji parafialnych) „nie są wykluczone jednak nowe formy [przepowiadania], byleby tylko okazały się skuteczne w integralnym głoszeniu Ewangelii i popieraniu wzrostu życia chrześcijańskiego" (De verbi Dei predicazione, can. 770, w: Codice di Diritto Canonico commentato. Testo ufficiale latino. Traduzione italiana. Fonti interpretazioni autentiche. Legislazione complementare della Conferenza Episcopale Italiana. Commento, a cura di Redazione di Quaderni di diritto ecclesiale, Milano 2001, s. 647).

${ }_{16}$ Pontificia Commissio Codici Iuris Canonici Recognoscendo, Schema canonum libri III 1977, can. 23 . 
O omawianych tu innych formach praedicatione mówią późniejsze projekty KPK. W schemacie $\mathrm{z} 1980$ roku kwestia ta została sformułowana $\mathrm{w}$ następujący sposób: „Parochi certis temporibus, iuxta Episcopi dioecesani praescripta, illas ordinent praedicationes, quas exercitia spiritualia missionesve vocant, aliasve necessitatibus aptatas" ${ }^{\text {"17 }}$. Natomiast w Schema novissimum sformułowano ją tak: „Parochi certis temporibus, iuxta Episcopi dioecesani praescripta, illas ordinent praedicationes, quas exercitia spiritualia et sacras missiones vocant, vel alias formas necessitatibus aptatas”18.

Owe „inne formy przepowiadania dostosowane do miejscowych potrzeb” są wyraźnie wspomniane w Enchiridion indulgentiarum, gdzie prawodawca pisze: „\$1 Odpustu zupełnego udziela się wiernemu, który wysłuchawszy w czasie świętych misji kilku kazań, będzie uczestniczyć w uroczystym ich zakończeniu. $\$ 2$. Odpustu cząstkowego udziela się wiernemu, który uważnie i pobożnie będzie uczestniczyć $\mathrm{w}$ innego rodzaju przepowiadaniach słowa Bożego"19. Wymienione „innego rodzaju przepowiadania słowa Bożego” to to samo, co kodeksowe „inne formy przepowiadania dostosowane do miejscowych potrzeb", gdyż w $\$ 1$ wyraźnie wymienia się misje ludowe, a w $\$ 2$ jako różne od misji i od homilii „innego rodzaju przepowiadania słowa Bożego”. Te „innego rodzaju przepowiadania słowa Bożego” nie są też rekolekcjami, gdyż o tych mówi się w innym miejscu Enchiridion indulgentiarum ${ }^{20}$.

\section{2. Źródła i treść „innych form przepowiadania" słowa Bożego}

Jak każda kościelna posługa słowa, także „inne formy przepowiadania” słowa Bożego winny mieć jako treść tajemnicę Chrystusa. Kanon 760 postanawia, że „w posłudze słowa, która winna się opierać na Piśmie Świętym, Tradycji, liturgii, Nauczycielskim Urzędzie i życiu Kościoła, należy przedstawiać w całości i wiernie tajemnicę Chrystusa”. Przedstawianie tej tajemnicy charakteryzują dwa przysłówki: integre ac fideliter („w całości i wiernie”) ${ }^{21}$. „Aby «danina jego

${ }_{17}$ Schema Codicis Iuris Canonici, Libreria Editrice Vaticana 1980, can. 725.

${ }_{18}$ Codex Iuris Canonici, Schema novissimum iuxta placita Patrum Commissionis emendatum atque Summo Pontifici praesentatum, Typis Polyglottis Vaticanis 1982, can. 770.

19 Paenitentiaria Apostolica, Enchiridion indulgentiarum quarto editur, 16.07.1999, Libreria Editrice Vaticana 1999, Exercitia spiritalia et recollectio menstrua, Concessione $\mathrm{nr} 16 \$ 2$.

${ }^{20}$ Concessione $\mathrm{nr} 10 \$ 1$.

${ }^{21}$ Kan. 760. 
wiary» była doskonała, każdy z uczniów Jezusa ma prawo otrzymać «słowo wiary», pełne i całkowite w swej ostrości i sile”22.

Posługa słowa musi zatem znajdować swoje źródła w Piśmie Świętym, w Tradycji, w liturgii, w Magisterium i w życiu Kościoła. Kodeks w kan. 760 przyjął te wyrażenia (źródła) z dekretu o pasterskich zadaniach biskupów w Kościele Vaticanum II, gdzie sobór odnosi je do katechezy, co oczywiście obowiązuje w każdym przejawie munus docendi. W dekrecie tym czytamy: „to nauczanie [katechetyczne] winno opierać się na Piśmie świętym, Tradycji, liturgii, na Magisterium i życiu Kościoła”23.

Ratio fundamentalis institutionis sacerdotalis z 19 marca 1985 roku odnośnie do oparcia przepowiadania na Piśmie Świętym postanawia: „Pismo święte jest jakby duszą całej teologii; ono winno kształtować wszystkie dyscypliny teologiczne. Z tego względu należy przyznać należne znaczenie nauczania Biblii. Profesorowie winni [...] przekazać alumnom teologiczną syntezę Bożego Objawienia, aby zapewnić trwałe podstawy ich życiu duchowemu i przyszłemu przepowiadaniu"24.

Natomiast Directorium Catechisticum Generale z 1971 roku zawiera w tej kwestii zapis: „treść katechezy zawiera się w słowie Bożym pisanym lub przekazywanym; bardziej jest ona zgłębiana i wyjaśniana przez wierny lud pod kierownictwem Nauczycielskiego Urzędu, który sam tylko naucza w sposób autentyczny; jest przedmiotem czci liturgii, jaśnieje w życiu Kościoła, zwłaszcza w sprawiedliwych i świętych. Wreszcie w jakiś sposób może być rozpoznana

${ }^{22}$ Joannes Paulus P.P. II, Adhortatio apostolica, Catechesi tradendae [dalej: CT] 16.10.1979, nr 30, „Acta Apostolicae Sedis” 71 (1979), s. 1277-1340; tekst polski: Katecheza po Soborze Watykańskim II w świetle dokumentów Kościoła, red. W. Kubik, cz. II, Warszawa 1985, s. 146-217; por. P. Urso, Il ministero della parola divina: predicazione e catechesi (cann. 756-780), w: La funzione di insegnare della Chiesa, a cura di Gruppo Italiano Docenti di Diritto Canonico, Milano 1994, s. 28.

${ }^{23}$ Concilium Oecumenicum Vaticanum II, Decretum de pastorali Episcoporum munere in Ecclesia Christus Dominus, nr 14, "Acta Apostolicae Sedis” 58 (1966), s. 673-701; tekst polski: Sobór Watykański II, Dekret o pasterskich zadaniach biskupów w Kościele Christus Dominus, w: Sobór Watykański II, Konstytucje, dekrety, deklaracje. Tekst polski, nowe tłumaczenie, Poznań 2002, S. 236-258; „Mówić o Tradycji i o Piśmie świętym jako o źródle katechezy, to podkreślać, że powinna ona być przepełniona i przeniknięta myślą, duchem i podstawami biblijnymi i ewangelicznymi przez stały kontakt z samymi tekstami, ale także przypominać, że katecheza będzie o tyle bogatsza i skuteczniejsza, o ile odczytywać będzie słowa według myśli i ducha Kościoła; powinna się inspirować myślą i życiem dwóch tysięcy lat Kościoła” (CT 27).

${ }^{24}$ Sacra Congregazione per l'Educazione Cattolica, Ratio fundamentalis institutionis sacerdotalis, 19.03.1985, Typis Polyglottis Vaticanis 1985, nr 78. 
w nieskażonych wartościach moralnych, które z Bożej Opatrzności istnieją w społeczności ludzkiej”25.

Omawiane „inne formy przepowiadania” słowa Bożego winny z pewnością zawierać przede wszystkim to, w co należy wierzyć i co trzeba czynić dla chwały Bożej i zbawienia ludzi, także naukę, jaką Urząd Nauczycielski Kościoła głosi o godności i wolności osoby ludzkiej, o jedności i trwałości rodziny oraz o jej zadaniach, o obowiązkach ludzi żyjących w społeczeństwie, jak również o układaniu spraw doczesnych zgodnie z porządkiem ustanowionym przez Boga ${ }^{26}$.

Odnośnie do treści przepowiadania w rekolekcjach czy misjach parafialnych Schemat KPK Z 1977 roku przypomina, że podczas tych akcji duszpasterskich „przedstawia się wiernym podstawowe prawdy nauki chrześcijańskiej” ${ }^{27}$.

We wszystkich formach przepowiadania obowiązuje postanowienie kan. 769, w myśl którego „naukę chrześcijańską należy wykładać w sposób dostosowany do poziomu słuchaczy, z uwzględnieniem potrzeb czasu”. Na temat przystosowania języka przepowiadania do możliwości audytorium i uwzględnienia potrzeb czasów pisał papież Paweł vi: „Kościoły partykularne, głęboko zmieszane nie tylko $\mathrm{z}$ ludami, ale także $\mathrm{z}$ ich pragnieniami, bogactwami i ograniczeniami, z ich sposobami modlenia się, kochania, patrzenia na życie i świat - co wszystko wyróżnia daną społeczność ludzką - powinny przyswoić sobie trzon ewangelizacyjnego orędzia i, bez najmniejszej zmiany zasadniczej jego prawdy, przełożyć je na język zrozumiały dla miejscowych ludzi, a potem je w tym języku głosić" ${ }^{28}$. Takiego sposobu przepowiadania winni uczyć się alumni, którzy w przyszłości będą pełnić posługę słowa: „przekazywane kształcenie naukowe dotyczy tego, by alumni, wraz z ogólną kulturą odpowiadającą potrzebom miejsca i czasu, otrzymali obszerną i solidną znajomość nauk świętych, tak by opierając się na nich i karmiąc nimi swoją wiarę, mogli głosić naukę Ewangelii współczesnym sobie ludziom w sposób odpowiedni i przystosowany do ich mentalności”29.

25 Directorium Catechisticum Generale, 11.04.1971, Libreria Editrice Vaticana 1971, nr 45; tekst polski: Ogólna instrukcja katechetyczna, „Wiadomości Archidiecezjalne Warszawskie” 63 (1973) $\mathrm{nr} 2$, s. 37-112; por. P. Urso, Il ministero della parola divina, dz. cyt., s. 29.

${ }^{26}$ Zob. kan. 768; por. J. Dyduch, Misja przepowiadania w powszechnym prawodawstwie kościelnym, dz. cyt., s. 34 .

${ }^{27}$ Pontificia Commissio Codici Iuris Canonici Recognoscendo, Schema canonum libri III 1977, can. 23 .

${ }^{28}$ Adhortatio apostolica De evangelizatione in mundo huis temporis Evangelii nuntiandi, 8.12.1975, nr 63, „Acta Apostolicae Sedis” 68 (1976), s. 5-76.

29 Kan. 248. 
W praktyce oznacza to używanie odpowiedniego języka i stylu mówienia, który może być zrozumiały przez poszczególnych wiernych. Na pewno wymaga to również unikania zawiłych i skomplikowanych wywodów i argumentacji, które - niezależnie od ich wartości w dyskursie akademickim, czy w innych tego typu środowiskach - w niewielkim stopniu, jeśli w ogóle, mają wkład $\mathrm{w}$ zrozumienie ewangelii przez przeciętnego słuchacza ${ }^{30}$.

\section{Ważniejsze rodzaje „innych form przepowiadania" parafialnego}

Prawodawca kodeksowy w kan. 770 nie wymienia, nawet egzemplarycznie, konkretnych rodzajów omawianych „innych form przepowiadania” słowa Bożego. Doprecyzowanie tej kwestii pozostawia regulacji partykularnej. Ma się to dokonywać „zgodnie z zarządzeniem biskupa diecezjalnego”, z uwzględnieniem miejscowych potrzeb ${ }^{31}$.

Kanoniści, komentując kan. 770, wymieniają przykładowo różne „inne formy przepowiadania” w parafii. José Fuentes pisze, że „istnieje wiele innych form przepowiadania. Teologowie i liturgiści rozróżniają różne rodzaje przepowiadania, biorąc pod uwagę przede wszystkim treść i wiernych, do których są kierowane; mówią o przepowiadaniu kerygmatycznym, parenetycznym, liturgicznym, i tak dalej"32.

Francis Morrisey zauważa, że istnieje wiele form ćwiczeń duchownych, w ramach których może mieć miejsce przepowiadanie słowa Bożego: dni skupienia, czuwania, spotkania modlitewne, kazania wielkopostne albo adwentowe itp., które winny być dostosowane do warunków lokalnych ${ }^{33}$.

$3^{3}$ Por. F. Morrisey, The Teaching Office of the Church can. 769, w: The Canon Law Letter and Spirit..., dz. cyt., s. 426. „Głosiciele Słowa Bożego, unikając słów mądrości ludzkiej i niejasnych argumentów, niech głoszą chrześcijanom integralną tajemnicę Chrystusa” (Codex Canonum Ecclesiarum Orientalium. Auctoritate Ioannis Pauli PP. II promulgatus, Typis Polyglottis Vaticanis 1990 oraz „Acta Apostolicae Sedis” 82 [1990], s. 1033-1363; tłumaczenie polskie: Kodeks kanonów Kościołów wschodnich, Lublin 2002, kan. $616 \$ 1$ ). W kwestii języka zarówno homilii, jak i wszelkich form głoszenia słowa Bożego Zdzisław Janiec zauważa, że należy unikać wszelkich archaizmów, tj. żargonu teologicznego, jak i pobożnej frazeologii. Zob. Z. Janiec, Homilia liturgiczna, „Anamnesis” 11 (2005) nr 41, s. 140.

${ }^{31}$ Zob. kan. 770.

${ }^{32}$ J. Fuentes, Comentario al can. 770 , dz. cyt., s. 124.

${ }_{33}$ Por. F. Morrisey, The Teaching Office of the Church can. 770, dz. cyt., s. 426; zob. H. Mussinghoff, Exerzitien und Volksmissionen, kan. 770, w: Münsterischer Kommentar zum Codex Iuris Canonici, Hrsg. K. Lüdicke, t. 3, Essen 1988-2001, kan. 770/1. 
Jan Dyduch pisze, że „prawodawca przewiduje jeszcze inne formy przepowiadana dostosowane do miejscowych potrzeb. Mogą to być kazania tematyczne głoszone na nabożeństwach stanowych, czerwcowych, październikowych. Mogą to być też kazania katechizmowe lub tzw. przepowiadanie seryjne, np. na Gorzkich Żalach, czy kazania w czasie Nowenny do Matki Bożej Nieustającej Pomocy lub innych nowennach"34.

Wydaje się, że kan. 761, mówiąc o stosowaniu różnych dostępnych środków do głoszenia nauki chrześcijańskiej m.in. o akademiach, konferencjach i różnego rodzaju zebraniach, obejmuje także owe „inne formy przepowiadania” słowa Bożego w parafii ${ }^{35}$.

Redaktorzy dyrektorium Ecclesiae imago wyliczają egzemplarycznie „inne formy przepowiadania” w parafii, gdy mówią o specjalnych okazjach do nauczania biskupiego: „niech Biskup nie pominie żadnej nadarzającej się okazji przemawiania do wiernych, prowadząc rozmowę lub wykład na tematy religijne. Chodzi zwłaszcza o pewne grupy osób, jak np. nauczycieli, pisarzy i dziennikarzy, piastujących władzę, związanych z środkami masowego przekazu; jednym słowem idzie o wszystkich, którzy są w jakiś sposób związani z wychowaniem, informacją i rozpowszechnianiem wiadomości (opinii)"36. Wspomniana rozmowa lub wykład na tematy religijne może mieć miejsce także w parafii. Ten sam dokument mówi o katechezach przed przyjęciem sakramentów albo podczas samego ich udzielania, o „katechezie uporządkowanej”, obejmującej wykłady przystosowane do grup różnego wieku, prowadzonej w kościołach i miejscach odpowiednich ${ }^{37}$, o nabożeństwach biblijnych, czasie których wśród modlitw i śpiewów ma miejsce publiczna lektura i rozważanie Pisma Świętego ${ }^{38}$.

${ }^{34}$ J. Dyduch, Misja przepowiadania w powszechnym prawodawstwie kościelnym, dz. cyt., s. 31.

${ }^{35}$ Comentario exegético al Código de Derecho Canónico traktuje kan. 761 jako korespondujący m.in. z kan. 770. Zob. J. Fuentes, Comentario al can. 761, dz. cyt., s. 96.

${ }^{36}$ Sacra Congregatio pro Episcopis, Directorium Ecclesiae imago de pastorali ministerio Episcoporum [dalej: EI], 22.02.1973, nr 61, w: Enchiridion Vaticanum, t. 4, Bologna 1997, nr 1945-2328; tekst polski: Posoborowe prawodawstwo kościelne, zebr. i przetł. E. Sztafrowski, Warszawa 1975, t. 6, z. $1, \mathrm{nr} 10370-11035$.

37 Zob. EI 64 bc.

${ }^{38}$ Zob. EI 92. W czasie nabożeństw biblijnych występuje też przepowiadanie słowa Bożego. 
Dyrektorium o pasterskiej postudze biskupów wylicza przykładowo „inne formy przepowiadania" w parafii: lekcje, konferencje, dyskusje, okrągły stół ${ }^{39}$, spotkania na temat duchowości, kursy ${ }^{40}$.

Direttorio Generale per la Catechesi jako miejsca przepowiadania słowa Bożego w parafii przewiduje „spotkania przedsakramentalne przygotowanie do małżeństwa, do chrztu i do pierwszej Komunii świętej dzieci” ${ }^{\text {11 }}$.

Direttorio omiletico z 2014 roku obok pozytywnego opisu natury homilii i jej definicji wskazuje również drogą negacji (via negativa), czym homilia nie jest: lekcją, konferencją, kazaniem, egzegezą, katechezą, świadectwem osobistym kaznodziei, moralizatorską nauką. Wszystkie te elementy mogą jednak współtworzyć homilię̨ ${ }^{42}$. Pośrednio więc Direttorio omiletico artykułuje omawiane w artykule dopuszczalne ,inne formy przepowiadania” w parafii: lekcja, konferencja, kazanie, egzegeza, katecheza, świadectwo, moralizatorska nauka. $\mathrm{Na}$,inne formy przepowiadania” w parafii wskazuje też wspomniane dyrektorium, gdy mówi: „Lud boży ma wielkie pragnienie pogłębiać znajomość Pisma Świętego i pasterze muszą przewidzieć okazje i inicjatywy, które pozwolą wiernym pogłębić znajomość słowa Bożego"43.

Prawodawcy partykularni wymieniaja jako ,inne formy przepowiadania” w parafii: nauki (kazania) katechizmowe ${ }^{44}$, nabożeństwa słowa Bożego ${ }^{45}$, kręgi

39 Congregaticio pro Episcopis, Direttorio per il ministero pastorale dei vescovi Apostolorum Successores, 22.02.2004, Città del Vaticano 2004, nr 130; tekst polski: Kongregacja do spraw Biskupów, Dyrektorium o pasterskiej posłudze biskupów Apostolorum Successores [dalej: Apostolorum Successores], 22.02.2004, Kielce 2005.

40 Apostolorum Successores, $\mathrm{nr} 116$.

${ }^{41}$ Congregazione per il Clero, Direttorio Generale per la Catechesi, 15.08.1997, Libreria Editrice Vaticana 1997, nr 258 b; tekst polski: Kongregacja ds. Duchowieństwa, Dyrektorium ogólne o katechizacji, Poznań 1998.

${ }^{42}$ Zob. Congregazione per il Culto Divino e la Disciplina dei Sacramenti Direttorio omiletico, 29.06.2014, Città del Vaticano 2014, nr 6; H. Sławiński, Znaczenie, geneza i struktura „Dyrektorium homiletycznego”, „Polonia Sacra” 19 (2015) nr 3, s. 168.

43 Direttorio omiletico, $\mathrm{nr} 6$.

${ }_{44}$ Zob. Ustawa Synodalna Diecezji Radomskiej promulgowana przez Biskupa Radomskiego Edwarda Materskiego 5 kwietnia 1997 roku w Radomiu na I Synodzie Diecezji Radomskiej, Radom 1999, st. 97 \$1, s. 47; Sacra Congregatio Concilii, Lettera circolare, 31.05.1920, „Acta Apostolicae Sedis” 12 (1920), s. 299-300; X. Ochoa, Leges Ecclesiae post Codicem iuris canonici editae, vol. 1, Roma 1966, col. 314-315. W okólniku tym Święta Kongregacja Soboru zapytuje ordynariuszy Włoch, „czy wszyscy proboszczowie i ci, którym powierzono duszpasterstwo, objaśniają ludowi Ewangelię we wszystkie niedziele i inne święta nakazane" (tłumaczenie własne).

${ }^{45}$ Zob. Drugi Synod Diecezji Włocławskiej. Statuty. Włocławek 1994, st. 14, s. 10. 
biblijne i liturgiczne ${ }^{46}$, konferencje ${ }^{47}$, kazania na gorzkich żalach, w pierwsze piątki miesiąca, podczas nowenny do Matki Bożej Nieustającej Pomocy ${ }^{48}$, tridua, dni skupienia dla poszczególnych stanów ${ }^{49}$, wykłady ${ }^{50}$, egzorty ${ }^{51}$, sym- $^{-}$ pozja $^{52}$.

\section{Podsumowanie}

1. Jedną z zasadniczych posług proboszcza $\mathrm{w}$ parafii jest przepowiadanie słowa Bożego. Wspólnota parafialna ma prawo domagania się od niego pełnienia tej posługi w omówionym zakresie.

2. Wśród środków przekazu słowa Bożego w parafii szczególne miejsce zajmuje homilia, będąca częścią liturgii.

3. Oprócz obowiązkowego głoszenia homilii w parafii należy w pewnych okresach organizować misje ludowe i rekolekcje, ale zgodnie z zarządzeniem biskupa diecezjalnego.

4. Poza misjami i rekolekcjami proboszczowie zgodnie z zarządzeniem biskupa diecezjalnego powinni w pewnych okresach organizować inne formy przepowiadania dostosowane do miejscowych potrzeb.

5. Jak każda kościelna posługa słowa, także „inne formy przepowiadania” słowa Bożego winny mieć jako treść tajemnicę Chrystusa. Kanon 760 KPK postanawia, że „W posłudze słowa, która winna się opierać na Piśmie świętym, Tradycji, liturgii, Nauczycielskim Urzędzie i życiu Kościoła, należy przedstawiać w całości i wiernie tajemnicę Chrystusa”.

6. W „innych formach przepowiadania” obowiązuje postanowienie kan. 769 K PK, w myśl którego „naukę chrześcijańską należy wykładać w sposób dostosowany do poziomu słuchaczy, z uwzględnieniem potrzeb czasu”. W praktyce

${ }^{46}$ Zob. Drugi Synod Diecezji Włocławskiej. Statuty, dz. cyt., st. 18, s. 12.

47 Zob. IV Synod Diecezji Tarnowskiej: Ad imaginem ecclesiae universalis, Tarnów 1990, st. $7 \$ 1$, s. 72.

${ }^{8}$ Zob. IV Synod Diecezji Tarnowskiej: Ad imaginem ecclesiae universalis, dz. cyt., st. $9 \$_{3}$, s. 73 .

49 Zob. IV Synod Diecezji Tarnowskiej: Ad imaginem ecclesiae universalis, dz. cyt., st. $9 \S_{3}$, nr 2, s. 73 .

${ }^{5}$ Zob. Biskup Siedlecki, Dekret ustanawiający Diecezjalne Sanktuarium Miłosierdzia Bożego w kościele parafialnym pw. Chrystusa Miłosiernego w Białej Podlaskiej, 26.12.2003, „Wiadomości Diecezjalne Siedleckie" 73 (2004) nr 1, s. 16.

${ }_{51}$ Zob. Statut sanktuarium św. Andrzeja Boboli w Strachocinie, 16.01.2007, „Kronika Archidiecezji Przemyskiej" 92 (2007) nr 21, s. 47.

${ }_{52}$ Zob. Statut sanktuarium św. Andrzeja Boboli w Strachocinie, dz. cyt., nr 23, s. 47. 
oznacza to używanie odpowiedniego języka i stylu mówienia, który może być zrozumiały przez poszczególnych wiernych.

7. Prawodawca kodeksowy w kan. 770 nie wymienia, nawet egzemplarycznie, konkretnych rodzajów omawianych „innych form przepowiadania” słowa Bożego w parafii. Doprecyzowanie tej kwestii pozostawia regulacji partykularnej. Ma się to dokonywać „zgodnie z zarządzeniem biskupa diecezjalnego” z uwzględnieniem miejscowych potrzeb.

\section{ABstrakt}

Celem artykułu jest ukazanie innych (różnych od misji czy rekolekcji parafialnych) form przepowiadania słowa Bożego, dostosowanych do miejscowych potrzeb, które proboszczowie winni organizować zgodnie z zarządzeniem biskupa diecezjalnego.

W jego pierwszej części przedstawiono różne formy przepowiadania słowa Bożego w parafii.

W drugiej części wskazano na źródła i treść „innych form przepowiadania” słowa Bożego, natomiast część trzecia została poświęcona ważniejszym rodzajom „innych form przepowiadania" parafialnego.

\section{SŁOWA KLUCZOWE}

homilia, przepowiadanie słowa Bożego, kazanie tematyczne, konferencja, nauki katechizmowe

\section{Abstract}

Selected Forms of Preaching the Word of God in the Parish (Can. 770 CIC) This article aims to show the other (different from the mission or parish retreats) forms of preaching of the word of God adapted to the local needs, which should be organised by the parish priests in accordance with the decision of the diocesan Bishop.

The first part of the article shows various forms of preaching of the word of God in the parish.

The second part points out the sources and content of "other forms of preaching" of the word of God. The third part examines important types of "other forms of preaching" in the parish.

\section{KeYWORDS}

homily, preaching the word of God, thematic sermon, lectures, teaching catechism 


\section{BIBLIOGRAFIA}

\section{Źródła}

Sacra Congregatio pro Episcopis, Directorium Ecclesiae imago de pastorali ministerio Episcoporum, 22.02.1973, w: Enchiridion Vaticanum, t. 4, Bologna 1997, nr 19452328; tekst polski: Posoborowe prawodawstwo kościelne, zebr. i przetł. E. Sztafrowski, Warszawa 1975, t. 6, z. 1, nr 10370-11035.

Biskup Siedlecki, Dekret ustanawiający Diecezjalne Sanktuarium Miłosierdzia Bożego w kościele parafialnym pw. Chrystusa Miłosiernego w Białej Podlaskiej, 26.12.2003, „Wiadomości Diecezjalne Siedleckie” 73 (2004) nr 1, s. 16.

Codex Canonum Ecclesiarum Orientalium. Auctoritate Ioannis Pauli PP. II promulgatus, Typis Polyglottis Vaticanis 1990 oraz „Acta Apostolicae Sedis” 82 (1990), S. 1033-1363; tłumaczenie polskie: Kodeks kanonów Kościołów wschodnich, Lublin 2002.

Codex Iuris Canonici. Schema novissimum iuxta placita Patrum Commissionis emendatum atque Summo Pontifici praesentatum, Typis Polyglottis Vaticanis 1982.

Concilium Oecumenicum Vaticanum II, Decretum de pastorali Episcoporum munere in Ecclesia Christus Dominus, „Acta Apostolicae Sedis” 58 (1966), s. 673-701; tekst polski: Sobór Watykański II, Dekret o pasterskich zadaniach biskupów w Kościele Christus Dominus, w: Sobór Watykański II. Konstytucje, dekrety, deklaracje. Tekst polski, nowe tłumaczenie, Poznań 2002, s. 236-258.

Congregaticio pro Episcopis, Direttorio per il ministero pastorale dei vescovi, 22.02.2004, Città del Vaticano 2004; tekst polski: Kongregacja do spraw Biskupów, Dyrektorium o pasterskiej posłudze biskupów Apostolorum Successores, 22.02.2004, Kielce 2005.

Congregazione per il Clero, Direttorio Generale per la Catechesi, 15.08.1997, Libreria Editrice Vaticana, 1997; tekst polski: Kongregacja ds. Duchowieństwa, Dyrektorium ogólne o katechizacji, Poznań 1998.

Congregazione per il Clero, Istruzione Il presbitero, pastore e guida della comunità parrocchiale, 4.08.2002, Città del Vaticano 1999; tekst polski: Kongregacja ds. Duchowieństwa, Instrukcja Kapłan, pasterz i przewodnik wspólnoty parafialnej, Poznań 2002.

IV Synod Diecezji Tarnowskiej: Ad imaginem ecclesiae universalis, Tarnów 1990.

Diocesi di Milano. $47^{\circ}$ sinodo, Milano 1995.

Directorium Catechisticum Generale, 11.04.1971, Libreria Editrice Vaticana, 1971; tekst polski: Ogólna instrukcja katechetyczna, „Wiadomości Archidiecezjalne Warszawskie" 63 (1973) nr 2, s. 37-112.

Drugi Synod Diecezji Włocławskiej. Statuty, Włocławek 1994. 
Ioannes Paulus P.P. II, Adhortatio apostolica Catechesi tradendae, 16.10.1979, „Acta Apostolicae Sedis" 71 (1979), s. 1277-1340; tekst polski: Katecheza po Soborze Watykańskim II w świetle dokumentów Kościoła, red. W. Kubik, cz. 2, Warszawa 1985, s. $146-217$.

Missale Romanum ex decreto sacrocancti Oecumenici Concilii Vaticani II instauratum, auctoritate Pauli Pp. vi promulgatum, Ioannis Paulis Pp. II cura recognitum, editio typica tertia, dei 20 aprilis 2000, Typis Polyglottis Vaticanis 2002; tekst polski: Kongregacja Kultu Bożego i Dyscypliny Sakramentów, Ogólne wprowadzenie do Mszału rzymskiego, 20.04.200o, Poznań 2004.

Ordo Lectionum Missae, Editio typica altera, Libreria Editrice Vaticana 1981, Praenotanda.

Paenitentiaria Apostolica, Enchiridion indulgentiarum quarto editur, 16.07.1999, Libreria Editrice Vaticana 1999.

Paulus PP. VI, Adhortatio apostolica de evangelizatione in mundo huius temporis Evangelii nuntiandi, 8.12.1975, „Acta Apostolicae Sedis” 68 (1976), s. 5-76.

Pontificia Commissio Codici Iuris Canonici Recognoscendo, Schema canonum libri III - De ecclesiae munere docendi, Città del Vaticano 1977; tekst polski: Posoborowe prawodawstwo kościelne, zebr. i przetł. E. Sztafrowski, t. 11, z. 1, Warszawa 1980, $\mathrm{nr}$ 21077-21259.

Sacra Congregatio Concilii, Lettera circolare, 31.05.1920, „Acta Apostolicae Sedis” 12 (1920), s. 299-300; także w: Ochoa X., Leges Ecclesiae post Codicem iuris canonici editae, vol. 1, Roma 1966, kol. 314-315.

Sacra Congregazione per l'Educazione Cattolica, Ratio fundamentalis institutionis sacerdotalis, 19.03.1985, Typis Polyglottis Vaticanis 1985.

Schema Codicis Iuris Canonici, Libreria Editrice Vaticana 1980.

Statut sanktuarium św. Andrzeja Boboli w Strachocinie, 16.01.2007, „Kronika Archidiecezji Przemyskiej" 92 (2007) nr 21, s. 43-49.

Ustawa Synodalna Diecezji Radomskiej promulgowana przez Biskupa Radomskiego Edwarda Materskiego 5 kwietnia 1997 roku w Radomiu na I Synodzie Diecezji Radomskiej, Radom 1999.

\section{Literatura}

Bączkowicz F., Baron J., Stawinoga W., Prawo kanoniczne. Podręcznik dla duchowieństwa, t. 2, Opole 1958.

Brzozowski M., Nadolski B., Homilia, w: Encyklopedia katolicka, red. J. Walkusz i in., t. 6, Lublin 1993, k. 1175-1176.

The Canon Law Letter and Spirit a Practical Guide to the Code of Canon Law. Prepared by the Canon Law Society of Great Britain and Ireland in Association with The Canadian Canon Law Society, ed. F. Morrisey, London 1999. 
Codice di Diritto Canonico commentato. Testo ufficiale latino. Traduzione italiana. Fonti interpretazioni autentiche. Legislazione complementare della Conferenza Episcopale Italiana. Commento, a cura di Redazione di Quaderni di diritto ecclesiale, Milano 2001.

Comentario exegético al Código de Derecho Canónico, coord. y dirigida A. Marzoa, J. Miras, R. Rodríguez-Ocaña, vol. 3/1, Pamplona 2002 ${ }^{3}$.

Dyduch J., Misja przepowiadania w powszechnym prawodawstwie kościelnym, w: Stuga Słowa, red. W. Przyczyna, Kraków 1997, s. 23-35.

Głowa W., Liturgia miejscem i źródłem przepowiadania, Przemyśl 1999.

Janiec Z., Homilia liturgiczna, „Anamnesis” 11 (2005) nr 41, s. 138-140.

Miragoli E., Il termine „omelia” nei documenti della Chiesa, nei libri liturgici e nel Codice, „Quaderni di diritto ecclesiale” 11 (1998) n. 4, s. 340-356.

Münsterischer Kommentar zum Codex Iuris Canonici, Hrsg. K. Lüdicke, Bd. 3, Essen 1988-2001.

Pawluk T., Prawo kanoniczne według Kodeksu Jana Pawła II, t. 2: Lud Boży jego nauczanie $i$ uświęcanie, Olsztyn 1986.

Siwek G., Misje ludowe w teorii i praktyce Kościoła. Studium homiletyczne, Kraków 1999.

Siwek G., Misje ludowe, w: Leksykon teologii pastoralnej, red. R. Kamiński, W. Przygoda, M. Fiałkowski, Lublin 2006, s. 501-507.

Sławiński H., Znaczenie, geneza i struktura „Dyrektorium homiletycznego”, „Polonia Sacra" 19 (2015) nr 3, s. 155-176.

Urso P., Il ministero della parola divina: predicazione e catechesi (cann. 756-780), w: La funzione di insegnare della Chiesa, a cura di Gruppo Italiano Docenti di Diritto Canonico, Milano 1994, s. 25-49. 